\title{
Provenance Impacts Transplant Establishment and Adventitious Root Regeneration of Sycamore
}

\author{
Larry J. Shoemake, ${ }^{1}$ Michael A. Arnold, ${ }^{2}$ and Fred T. Davies, Jr. ${ }^{3}$ \\ Department of Horticultural Sciences, Texas A\&M University, M.S. 2133, College Station, TX 77843-2133
}

AdDitional Index words. Platanus occidentalis, landscape establishment, photosynthetic gas exchange, rooted cuttings, root growth potential, root regeneration potential, seed source, vegetative propagation

\begin{abstract}
A series of six experiments was conducted over eight years to investigate impacts of provenance on transplant establishment in landscapes and the role of adventitious root regeneration in differential genotypic responses during establishment of Platanus occidentalis L. Fall, spring, and summer transplants of container-grown half-sib families (HSF = seedlings derived from a single mother tree with unknown male parentage), including two selections native to Brazos County, Texas (Brazos-C, Brazos-D), one native to Cookeville, Tenn. (Cookeville), two Kentucky/Tennessee HSF from the Westvaco Corp. (WV-10, WV-14), and two Texas HSF from the Texas Forest Service tree improvement program (TFS-09, TFS-24), were established to determine field/landscape growth responses. Subsequent studies were conducted to investigate differential leaf gas exchange responses of TFS-09 and Cookeville during moderate water deficits and to determine root regeneration potential (RRP) responses of TFS-09, Brazos-C, WV-14, and Cookeville HSF following fall, spring, and summer transplant. To investigate consistency of within-family genotypic responses and to determine relationships among adventitious root initiation from shoot cuttings, RRP, and landscape establishment, five seedlings of TFS-09 and five from Cookeville HSF were clonally propagated and ramets tested under field and RRP conditions similar to those with seedling-derived plants. Regionally native HSF consistently grew taller, had larger trunk diameters, and often had greater survival during the first 3 years in the landscape than HSF not native to the region in which the studies were conducted. Rapidity of root regeneration among HFS at the time of transplant was the best root growth related predictor of successful landscape establishment. Some growth advantages were found using genetically improved HSF, but not as consistent an improvement as with the use of seedlings from regional provenances. Within-family variation in landscape performance was greater with nonregional Cookeville clones than with regional TFS-09 clones, however there was overlap among the more vigorous Cookeville clones and the least vigorous TFS-09 clones. Increased rapidity of root regeneration and drought adaptations related to leaf morphology and gas exchange characteristics may be involved in enhanced growth responses of Texas regional genotypes. No consistent relationships were found among adventitious rooting responses from shoot cuttings and subsequent RRP of the same genotypes from root tissues or their growth during the first 3 years in landscapes.
\end{abstract}

Establishment of landscape trees is difficult in the southwestern United States as favorable planting conditions are of limited duration (Arnold, 2002). Drought and heat typically limit establishment from late spring to late fall, while excess soil moisture can hinder winter and early spring transplanting. Winter temperatures may fluctuate from those favorable to growth $\left(20\right.$ to $\left.25^{\circ} \mathrm{C}\right)$ during the day to well below freezing at night. Although many of the same species utilized in the eastern United States are often grown in southwestern nurseries, their performance in the nursery and landscape is variable (Arnold, 2002). Ecotypic or within-species variation has been reported for numerous forest trees, and this variation has been successfully exploited for greater biomass accumulation, improved disease/pest resistance, straighter trunks, increased height, and/or more desirable branching patterns for several forest species (Zobel and Talbert, 1984; Zobel et al.,

Received for publication 5 Aug. 2003, in revised form on 21 Jan. 2004. Portions of this study were included as part of a thesis written in partial fulfillment of the requirements for the M.S. degree by L.J. Shoemake. The authors wish to thank the Lerio Corp., El Campo, Texas, for donation of containers. The authors also wish to acknowledge the assistance of W.J. Lowe of the Texas Forest Service for help with statistical analysis and provision of seed, R.J. Rousseau for seed from Westvaco Corp. genotypes, and Garry V. McDonald for technical assistance. These experiments were funded by the Texas Agricultural Experiment Station (TAES) and Texas Ornamental Enhancement Endowment. Mention of a trademark, proprietary product, or vendor does not constitute a guarantee or warranty of the product by the authors, the Texas A\&M University, or TAES and does not imply its approval to the exclusion of other products or vendors that also may be suitable.

${ }^{1}$ Former graduate teaching/research associate.

${ }^{2}$ Associate professor of landscape horticulture, corresponding author.

${ }^{3}$ Professor of horticulture.
1987). Recently, similar documentation of provenance responses for characteristics of interest in native species for ornamental plant nurseries and urban and suburban landscapes has begun (Arnold and Davis, 1994; Shoemake and Arnold, 1997; St. Hilaire and Graves, 2001; Zwack et al., 1999).

In recent years, the Texas Forest Service has selected superior phenotypes growing in urban sites for use in seed orchards to provide genetically superior seedlings for the landscape and nursery industry. Among these species was sycamore, Platanus occidentalis L., an important landscape species throughout much of the United States (Arnold, 2002; Odenwald and Turner, 1996; Sternberg and Wilson, 1995). Substantial intraspecific genetic variation has been documented in growth rate and form of sycamore (Nebgen, 1980; Wells and Toliver, 1987). Genetically improved HSF of sycamore were also available from an operational forest tree improvement program in a different region (Westvaco Corp., Wickliffe, Ky.). A previously tested less vigorous sycamore HSF from Tennessee (Arnold and Davis, 1994), and HSF from local nonimproved stands (Brazos County, Texas), were readily available. Hence, a range of provenances and genetically improved/ nonimproved genotypes were available for investigating potential genotype-by-environmental interactions related to nursery production and landscape performance characteristics of this species. Additionally, preliminary work indicated that sycamore rooted readily from cuttings, allowing propagation and testing of clonal as well as seeding genotypes, and has large white new roots that are easily differentiated from darker colored substrates when assessing RRP. Various measures of RRP have been found to be useful predictors of establishment of bareroot Liquidambar 
styraciflua L. (Kormanik, 1986) and container-grown Quercus shumardii Buckley (Arnold, 1996), but such relationships have not been investigated with $P$. occidentalis.

A series of six experiments was undertaken. Objectives of three of these experiments conducted with half-sib seedlings were to 1) document potential differential landscape establishment between local region and geographically distant provenances tested as HSF seedling populations from representative parental trees, 2) determine if performance during landscape establishment was related to HSF differences in initial RRP at the time of transplant to the field, and 3) begin preliminary investigations to determine if differential leaf gas exchange characteristics may contribute to differential field responses among HSF that establish vigorously and nonvigorously. Objectives of the three experiments with rooted cuttings and subsequent plants derived from them were to: 1) investigate variation among genotypes within a vigorous and nonvigorous HSF, 2) determine if any useful relationships exist between adventitious RRP of stem cuttings and subsequent container nursery and landscape establishment performance of those plants, and 3) determine if differences among HSF RRP were expressed when trees were vegetatively propagated.

\section{Materials and Methods}

HALF-SIB FAMILIES AND PLANTING DATE. Seedlings were grown in 9.3-L black plastic containers (Lerio Corp., El Campo, Texas) in a container nursery in College Station, Texas, as previously described (Shoemake and Arnold, 1997). Fall plantings were transplanted on 17 Nov. 1994, spring plantings on 10 Apr. 1995, and summer plantings on 12 June 1995. Half-sib families included two that were native to Brazos County, Texas (Brazos-C, Brazos-D), one native to Cookeville, Tenn. (Cookeville), two from the Westvaco Corp. in western Kentucky (WV-10, WV-14), and two from the Texas Forest Service tree improvement program (TFS-09, TFS24). Brazos-C, Brazos-D and Cookeville HFS were nonimproved genotypes, whereas TFS-09, TFS-24, WV-10, and WV-14 HSF were genetically improved selections. Texas genotypes are considered regional (test conditions were in Brazos County, Texas), whereas Kentucky and Tennessee genotypes are considered distant selections. Thirty trees from each HSF (210 trees per transplant date) were established on $1 \mathrm{~m}$ within-row and $3 \mathrm{~m}$ between-row spacings on a Boonville Series, Boonville fine sandy loam, fine, montmorillic thermic ruptic-vertic albaqualfs ( $\mathrm{pH} 9.1$, bulk density $1.51 \mathrm{~g} \cdot \mathrm{cm}^{-3}, 61 \%$ sand, $11 \%$ clay, $28 \%$ silt) in Brazos County, Texas. Irrigation was provided using $3.8 \mathrm{~L} \cdot \mathrm{h}^{-1}$ drip emitters daily as needed to maintain moisture in transplanted rootballs during the four weeks of establishment, and afterwards when soil water potentials reached $-1.5 \mathrm{kPa}$ (model 2725 JetFill tensiometers; Soil Moisture Equipment Corp., Santa Barbara, Calif.). Survival, height, and trunk diameter (15 cm above the root collar) were assessed at transplanting and yearly as plants entered fall dormancy in 1995, 1996, and 1997.

The statistical design was a seven $\mathrm{HSF} \times$ three planting date factorial with six blocks containing five randomized single plant replications per block. Family, block, experimental error, and sampling error were considered random effects, while transplant time was considered a fixed effect. Statistical anaylsis was performed using the general linear models procedures in SAS Systems for Windows, Release 6.12 (SAS Institute Inc., Cary, N.C.). Main effects are presented for only those characteristics not involved in significant $(P \leq 0.05)$ interactions. Percentage data were subjected to square-root transformation prior to analysis, but are presented in the text as nontransformed data.

ROOT GROWTH OF SEEDLING TRANSPLANTS. Seedlings of four HSF (TFS-09; Brazos-C, WV-14, and Cookeville) were grown in 2.8-L black plastic containers (Lerio Corp.) under the same container nursery growing conditions as those seedlings used in the HSF and planting date experiment. Concurrent with the field plantings in the HSF and planting date experiment, posttransplant RRP (initiation and subsequent elongation of new roots and elongation of intact root tips present at planting) was assessed for the initial three to four weeks following fall, spring, and summer transplant. Ten randomly selected seedlings per HSF were transplanted to individual $21.5 \times 21.5 \times 27.0 \mathrm{~cm}(12.5 \mathrm{~L})$ plexiglass root observation boxes (ROB) as described by Shoemake (1996). The ROB were constructed from clear plexiglass sheeting cut to fit the rectangular sizes and square bases. Sides and bases were attached to a frame of exterior treated $2.5-\mathrm{cm}$ quarter-round lumber using metal screws through predrilled holes in the plexiglass. Holes were drilled in the base to allow drainage. before planting, the rootball of each plant was sprayed with a $1 \%$ aqueous solution of methylene blue to facilitate distinction of regenerated roots from those present at planting per the methods of Arnold and Young (1990a). Root observation boxes were then enclosed in two black polyethylene bags to exclude light, except during data collection. Bags were drawn closed at the base of the trunk and ROB placed on greenhouse benches under natural photoperiods with nightly interruption from 2400 to $0400 \mathrm{HR}$ from $40-\mathrm{W}$ incandescent lamps suspended $1 \mathrm{~m}$ apart $1 \mathrm{~m}$ above the bench tops. Greenhouse atmospheric temperatures were recorded (model 8368-00 hygrothermograph; Cole-Parmer, Chicago, Ill.). The greenhouse was of fiberglass wall construction with a milky poly roof overlaid with a $55 \%$ light exclusion mesh black shade cloth. Root growth was observed at 3-d intervals on the four sides and bottoms of ROB. Every $3 \mathrm{~d}$, incremental elongation of root tips was traced on clear plastic sheets placed against the observation panels, thus allowing calculation of mean daily root elongation rates. Dates at which the first new root and first 10 new roots reached the observation panels were recorded. At final harvest of each transplanted group, the pine bark substrate in each ROB was carefully removed to determine additional measures of root regeneration including root diameters (measured at the mid-point of the root from base to tip), individual root length, and fresh and dry weights of roots. New roots were sorted into three size classes $(\mathrm{x} \leq 0.8 \mathrm{~mm}, 0.8 \mathrm{~mm}>\mathrm{x}<3.0 \mathrm{~mm}$, or $\mathrm{x} \geq$ $3.0 \mathrm{~mm}$ ) based on root diameter and counted. Every tenth root was randomly sampled for diameter and length determinations as roots in each size class were counted. Appropriate multipliers were used to calculate total root length, mean root diameter, and root surface area. Afterward, all new roots were dried at $70{ }^{\circ} \mathrm{C}$ for $3 \mathrm{~d}$ and weighed. Shoots and roots within the original planted rootball (roots and substrate within the original container volume transplanted to the ROB; delineated by methylene blue dye applications) were also harvested and dried. A completely random statistical design was used with four HSF $\times$ three planting dates factorial containing 10 single-plant replications. Family, experimental error, and sampling error were considered random effects, while transplant time was considered a fixed effect.

Water POTENTIAL AND $\mathbf{P}_{\mathbf{n}}$ GAS EXChange. Midday and predawn water potentials were determined at $0,7,14,21$, and $28 \mathrm{~d}$ posttransplant for five randomly selected trees per HSF and transplant date from the HSF and planting date transplant experiment. Xylem water potential measures were obtained using a portable pressure chamber (model 610; PMS Instruments, Corvallis, Ore.) as 
previously described (Shoemake, 1996; Shoemake and Arnold, 1997). Water potentials were determined using the most recently fully expanded leaf on the central leader of each tree. Leaves for midday water potentials were exposed to full sunlight.

In 1995, five seedlings from TFS-09 and Cookeville HSF were grown in 2.8-L black plastic containers (Lerio Corp.) under the same nursery conditions as previously described. On 20 Aug. 1995, plants were moved to a greenhouse to conduct leaf gas exchange measurements. Plants were allowed to acclimate for $24 \mathrm{~h}$ and watered to runoff the evening prior to the morning of measurement. In the morning, plants were moved under lamps that provided photosynthetic photon flux $>1000 \mu \mathrm{mol} \cdot \mathrm{m}^{-2} \cdot \mathrm{s}^{-1}$ (metal halide 1000-W GE multi-vapor MVR lights) with an intervening 8.2-cm-thick infrared irradiation water filter as described by Shoemake (1996) to protect the leaves from overheating. Net photosynthesis $\left(\mathrm{P}_{\mathrm{n}}\right)$, transpiration $(\mathrm{E})$, conductance $\left(\mathrm{g}_{\mathrm{s}}\right)$, and internal $\mathrm{CO}_{2}$ concentration of the leaves $\left(\mathrm{C}_{\mathrm{i}}\right)$ were measured according to the methods of Shoemake (1996) on the two most recently fully expanded leaves of each seedling using a Portable Photosynthesis System Model Li-6200 with a $\mathrm{CO}_{2}$ Analyser Model 6250 (LiCor, Lincoln, Nebr.). After measurements were recorded under these well watered conditions, irrigation was withheld for $2 \mathrm{~d}$ on half of the seedlings in each HSF to simulate a water deficit event. Concurrent xylem water potentials $\left(\Psi_{\text {xylem }}\right)$ were estimated under well watered (those with daily irrigation) and water-deficit

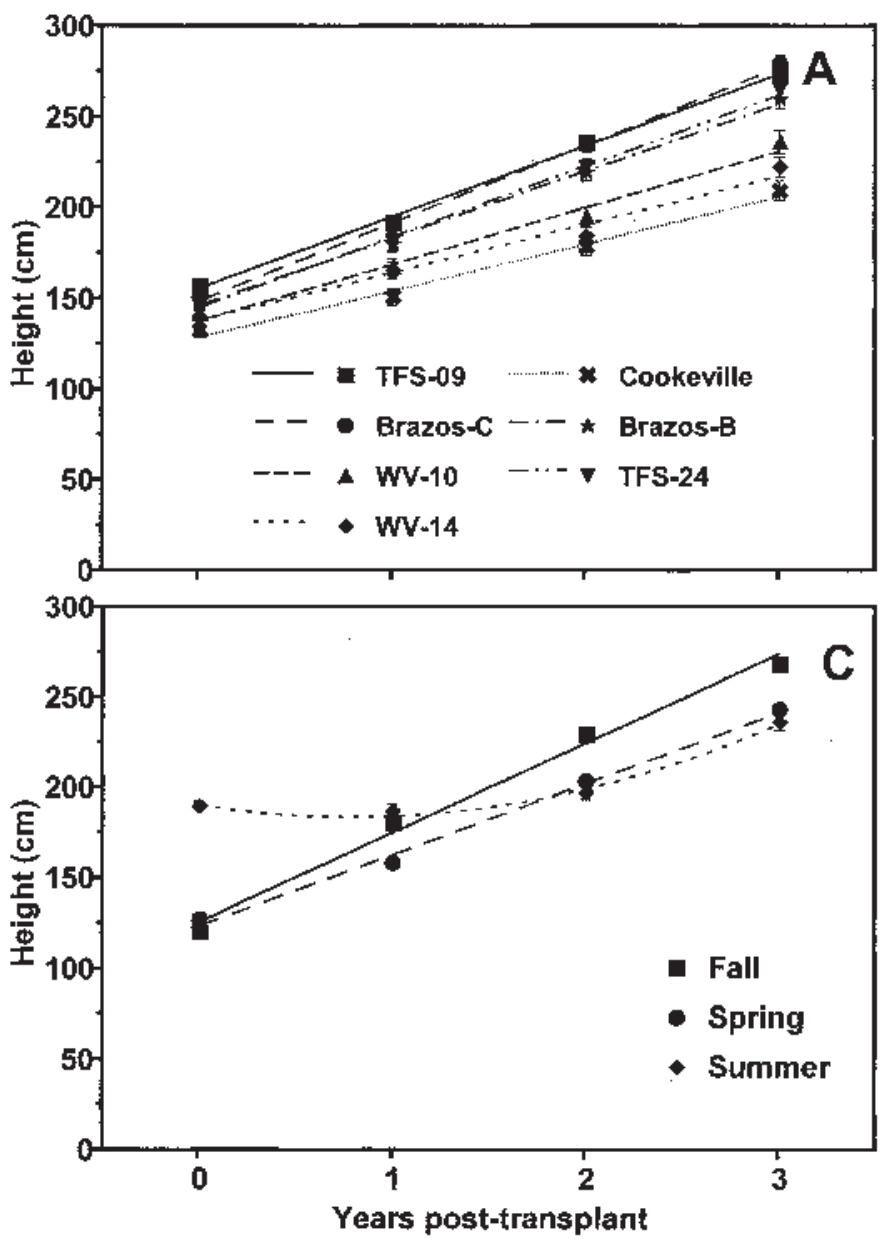

conditions (those with irrigation withheld) by using previously described methods (Shoemake and Arnold, 1997). After the water deficit set of measures was collected, total plant leaf surface area was quantified ( $\Delta \mathrm{T}$ area meter model ITC-47; ITC Delta $\mathrm{T}$ Devices, Ikegami Tsushinki, Japan).

AdVENTITIOUS ROOT REGENERATION FROM CUTTINGS. On 16 June 1997 (semi-hardwood), 12 Mar. 1998 (hardwood), and 20 May 1998 (softwood) terminal four-node cuttings were collected from five randomly selected seedlings (ortets) from TFS-09 (more vigorous) and Cookeville (less vigorous) HSF grown in the field portion of the HSF by transplant date experiment. Four replications of 10 cuttings (ramets) per seedling were placed in $38 \times 53 \times$ 10-cm black plastic flats (Kadon Corp., Dayton, Ohio) containing screened $(1.0 \mathrm{~cm})$ composted pine bark chips. Trays were placed in a greenhouse under intermittent mist $(6 \mathrm{~s}$ each $8 \mathrm{~min}$ from dawn to dusk) in a randomized complete block design with a group of 10 cuttings per treatment in each block. Natural photoperiods were used. After six weeks, adventitious rooting was assessed by recording the number of rooted cuttings in the block, number of roots regenerated on each cutting, number of roots with secondorder (branched) roots per cutting, and length of the three longest roots per cutting. Rooted semi-hardwood cuttings were potted in 2.8-L containers (Lerio Corp.) and grown until 25 Sept. 1997 to assess cutting survival in the container nursery. On 22 June 1998, 15 ramets of each clone were transplanted to 9.3-L black plastic
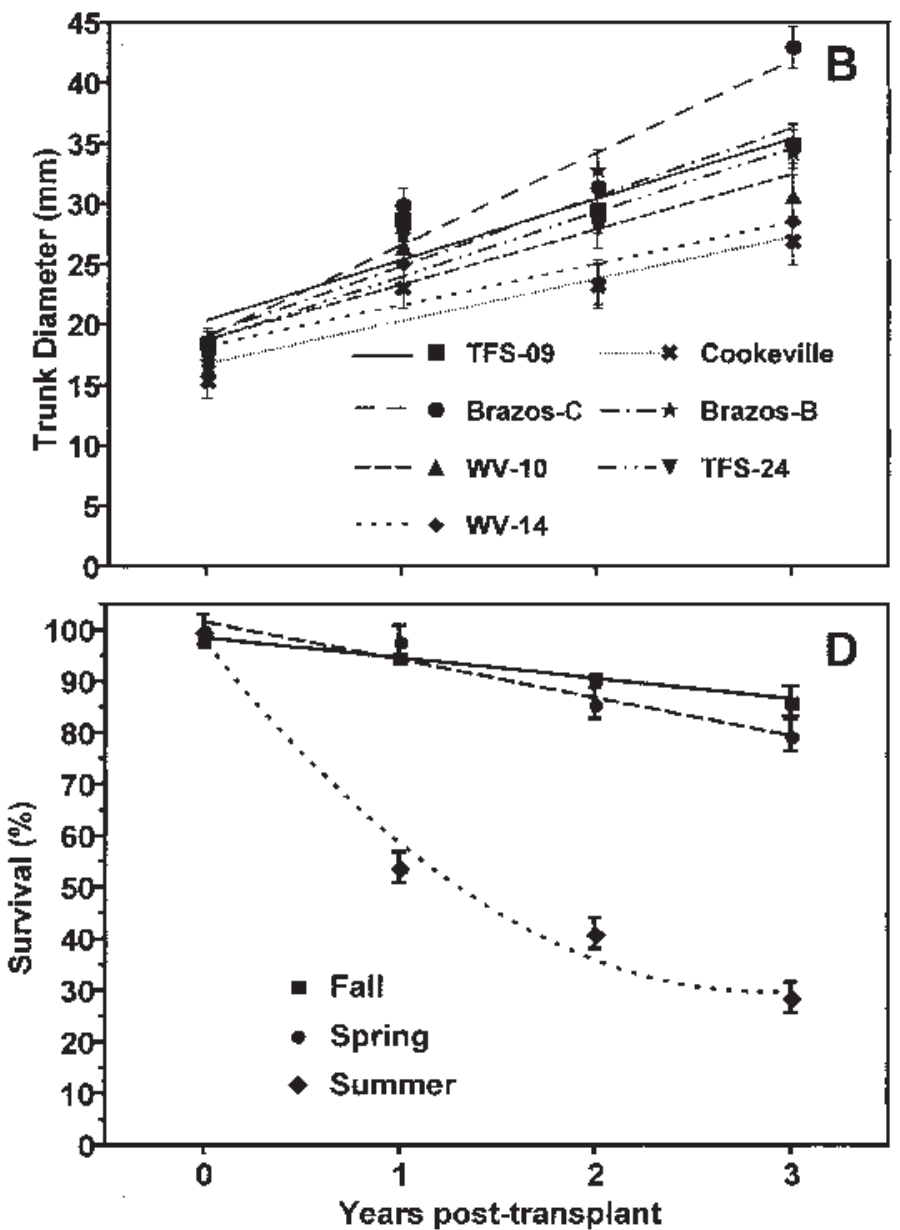

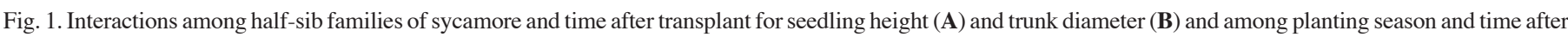

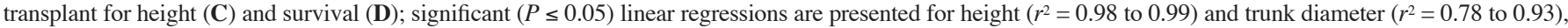

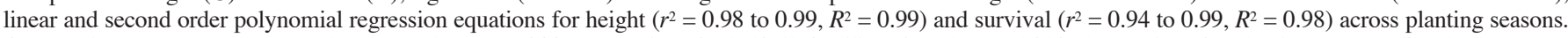
Observations represent means ( \pm the standard errors) of 90 observations for half-sib families (A and $\mathbf{B})$ and 210 observations for planting season (C and $\mathbf{D})$. 
containers (for later field transplant studies), and five ramets of each clone were transplanted to 7.1-Lblack plastic containers (for use in subsequent root-growth studies). Correlation analysis was performed between cutting rooting parameters and final survival, height, and trunk diameter measures in the field.

Field Responses of Clones. On 3 Nov. 1998, the surviving ramets grown in 9.3-L containers from the above study of adventitious root regeneration from cuttings were transplanted to the same field plots used to test landscape establishment of the seedling derived trees. Spacings and cultural conditions in the field were as described for the HSF and planting date experiment. The planting design was completely random with five clones from each of the two families (ten genotypes) and 15 ramets of each genotype.

ROOT GROWTH OF CLONES. On 4 Nov. 1998, surviving ramets of the five clones from within the Cookeville and TFS-09 HSF that were grown in 7.1-L black plastic containers (Lerio Corp.) during the study of adventitious root regeneration from cuttings were transplanted individually to ROB as previously described for seedling plants. Root regeneration measures were recorded as in the seedling root growth study.

\section{Results and Discussion}

Half-sib Families and Planting date. Half-sib family responses in the nursery and preliminary information on field responses were previously reported (Shoemake, 1996; Shoemake and Arnold, 1997), demonstrating the importance of provenance selection in container nursery production and initial landscape performance of seed propagated sycamore. Data presented herein extend this testing to a longer time in the landscape, determined the role of RRP and leaf gas exchange characteristics in observed growth responses, and investigated within-family variation and performance of vegetatively propagated genotypes.

After 3 years in the field, no significant three-way interactions $(P \leq 0.05)$ for height or trunk diameter were present among HSF, season of transplant, and years after transplant. However, significant two-way interactions were present for HSF and years after transplant for height (Fig. 1A) and trunk diameter (Fig. 1B) and between season of transplant and years after transplant for height (Fig. 1C). The greater height (Fig. 1A) and trunk diameter (Fig. 1B) growth reported for regional selections (native Texas HSF) continued to persist compared to nonregional selections for 3 years

Table 1. Main effects of selected half-sib families of Platanus occidentalis from different provenances on survival across transplant times. Trees were produced in 9.3-Lblack plastic containers and transplanted in fall, spring, or the subsequent summer. Post-transplant survival is after 3 years in a drip irrigated field with fine sandy loam soil in College Station, Texas (USDA hardiness zone 8b.).

\begin{tabular}{lc}
$\begin{array}{l}\text { Half-sib } \\
\text { family }\end{array}$ & $\begin{array}{c}\text { Surviving } \\
\text { trees } \\
(\%)\end{array}$ \\
\hline TFS-09 & $77 \mathrm{a}^{\mathrm{z}}$ \\
Brazos-C & $74 \mathrm{a}$ \\
Brazos-D & $64 \mathrm{ab}$ \\
TFS-24 & $60 \mathrm{~b}$ \\
WV-10 & $60 \mathrm{~b}$ \\
WV-14 & $59 \mathrm{~b}$ \\
Cookeville & $59 \mathrm{~b}$
\end{tabular}

${ }^{\mathrm{z}}$ Means followed by the same letter are not significantly different at $P \leq$ 0.05 using least squares means procedures, $\mathrm{n}=90$. after transplanting to the landscape. This is consistent with earlier reports on these genotypes by Shoemake and Arnold (1997). A small increase in growth could be achieved among nonregional genotypes by using improved HSF (WV-10 and WV-14 versus Cookeville), but differences between improved (TFS-09, TFS-
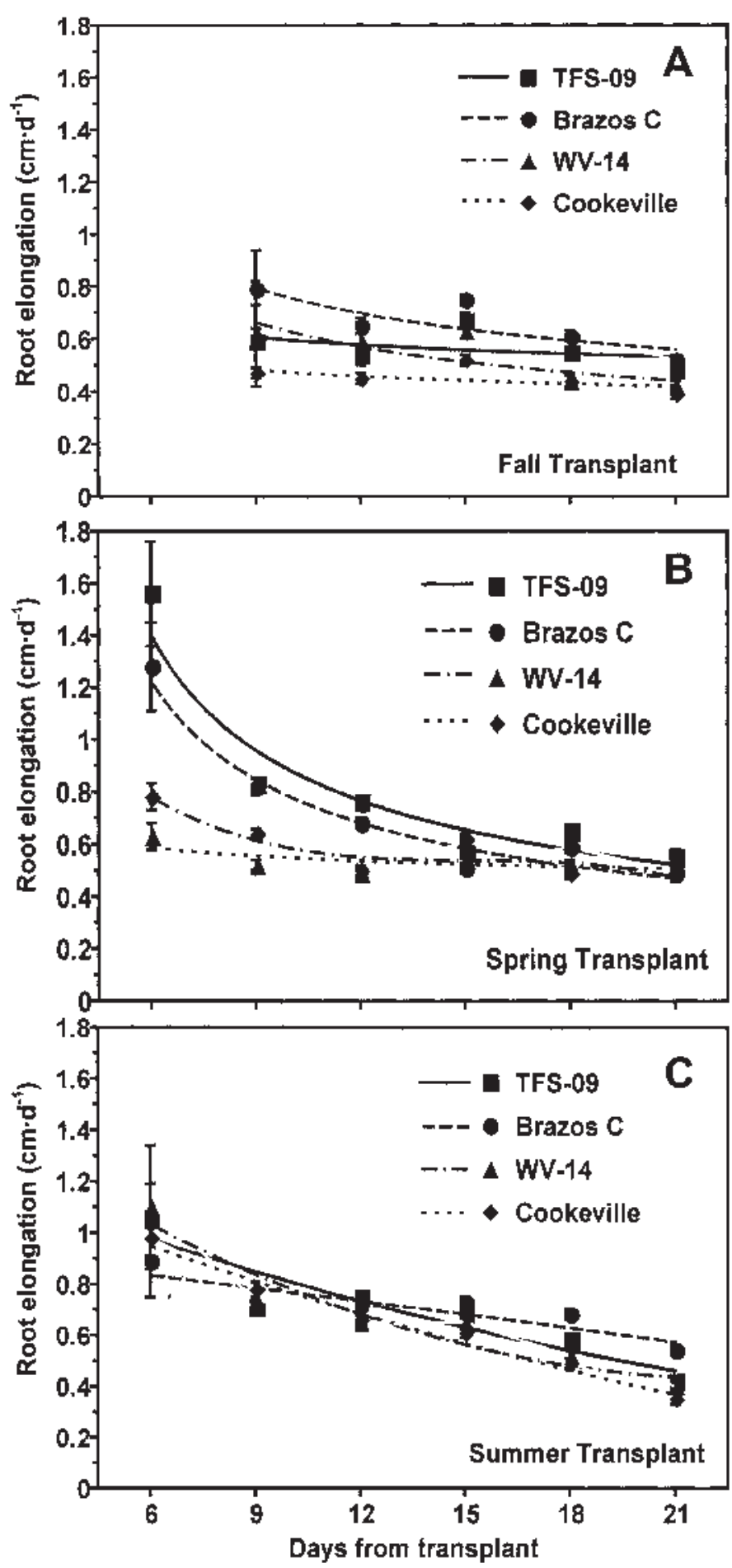

Fig. 2. Interactions among sycamore half-sib families and time after transplant on root elongation following fall (A), spring $(\mathbf{B})$, or summer $(\mathbf{C})$ transplant; values represent means ( \pm standard errors) of 10 plants with up to 40 observations per plant. Second-order polynomial regression equations were developed for each half-sib family for fall $\left(R^{2}=0.53\right.$ to $\left.R^{2}=0.80\right)$, summer $\left(R^{2}=0.24\right.$ to $R^{2}$ $=0.98)$, and spring $\left(R^{2}=0.76\right.$ to $\left.R^{2}=0.98\right)$ transplant. No roots were present at $6 \mathrm{~d}$ post-transplant for fall observations (A). 
Table 2. Interactions among various measures of root regeneration of seed-propagated half-sib families of sycamore and season of transplant during the first 21d after transplant from 7.1-L black plastic containers.

\begin{tabular}{|c|c|c|c|c|c|c|c|c|c|}
\hline \multirow[b]{3}{*}{$\begin{array}{l}\text { Transplant } \\
\text { season }\end{array}$} & \multirow[b]{3}{*}{$\begin{array}{l}\text { Half-sib } \\
\text { family }\end{array}$} & \multirow{3}{*}{$\begin{array}{l}\text { Days to } \\
\text { first } 10 \\
\text { roots }\end{array}$} & \multirow{2}{*}{\multicolumn{3}{|c|}{ Total new root }} & \multicolumn{4}{|c|}{ Dry wt (g) } \\
\hline & & & & & & \multirow[b]{2}{*}{$\begin{array}{l}\text { New } \\
\text { roots }\end{array}$} & \multirow[b]{2}{*}{$\begin{array}{l}\text { Total } \\
\text { plant }\end{array}$} & \multirow[b]{2}{*}{ Shoots } & \multirow{2}{*}{$\begin{array}{l}\text { Roots inside the } \\
\text { transplanted } \\
\text { rootball }\end{array}$} \\
\hline & & & Number & $\begin{array}{l}\text { Surface area } \\
\left(\mathrm{cm}^{2}\right)\end{array}$ & $\begin{array}{l}\text { Length } \\
(\mathrm{cm})\end{array}$ & & & & \\
\hline \multirow[t]{4}{*}{$\overline{\text { Fall }}$} & TFS-09 & $13 b^{z}$ & $488 \mathrm{ab}$ & $437 \mathrm{a}$ & $739 a$ & $1.3 \mathrm{ab}$ & $246.9 \mathrm{a}$ & $139.9 \mathrm{a}$ & $107.0 \mathrm{a}$ \\
\hline & Brazos-C & $11 \mathrm{c}$ & $568 \mathrm{a}$ & $572 \mathrm{a}$ & 99 a & $2.2 \mathrm{a}$ & $224.1 \mathrm{a}$ & $126.0 \mathrm{a}$ & $98.1 \mathrm{a}$ \\
\hline & WV-14 & $15 \mathrm{~b}$ & $268 \mathrm{bc}$ & $358 \mathrm{a}$ & $469 a$ & $0.6 \mathrm{ab}$ & $142.1 \mathrm{~b}$ & $77.7 \mathrm{~b}$ & $64.3 \mathrm{~b}$ \\
\hline & Cookeville & $20 \mathrm{a}$ & $98 \mathrm{c}$ & $87 \mathrm{a}$ & $128 \mathrm{a}$ & $0.2 \mathrm{~b}$ & $127.4 \mathrm{~b}$ & $64.2 \mathrm{~b}$ & $63.2 \mathrm{~b}$ \\
\hline \multirow[t]{4}{*}{ Spring } & TFS-09 & $11 \mathrm{c}$ & $1234 \mathrm{a}$ & $12683 \mathrm{a}$ & 4839 a & $7.0 \mathrm{a}$ & $316.5 \mathrm{a}$ & $218.1 \mathrm{a}$ & $98.4 \mathrm{~b}$ \\
\hline & Brazos-C & $12 \mathrm{bc}$ & $841 \mathrm{~b}$ & $9157 \mathrm{ab}$ & $3691 \mathrm{a}$ & $4.0 \mathrm{~b}$ & $239.3 \mathrm{~b}$ & $167.1 \mathrm{~b}$ & $72.2 \mathrm{a}$ \\
\hline & WV-14 & $14 \mathrm{ab}$ & $537 \mathrm{c}$ & $6252 \mathrm{~b}$ & 1772 b & $3.0 \mathrm{bc}$ & $214.0 \mathrm{bc}$ & $149.0 \mathrm{bc}$ & $65.0 \mathrm{bc}$ \\
\hline & Cookeville & $15 \mathrm{a}$ & $437 \mathrm{c}$ & $5646 \mathrm{~b}$ & $1626 b$ & $2.2 \mathrm{c}$ & $163.7 \mathrm{c}$ & $115.1 \mathrm{c}$ & $48.6 \mathrm{c}$ \\
\hline \multirow[t]{4}{*}{ Summer } & TFS-09 & $12 \mathrm{a}$ & $589 \mathrm{a}$ & 8461 a & $2682 \mathrm{a}$ & $5.5 \mathrm{~b}$ & $401.9 \mathrm{a}$ & $280.8 \mathrm{a}$ & $121.0 \mathrm{a}$ \\
\hline & Brazos-C & $11 \mathrm{a}$ & $717 \mathrm{a}$ & $11138 \mathrm{a}$ & $3753 \mathrm{a}$ & $7.3 \mathrm{a}$ & $403.6 \mathrm{a}$ & $296.5 \mathrm{a}$ & $107.1 \mathrm{a}$ \\
\hline & WV-14 & $13 \mathrm{a}$ & $596 \mathrm{a}$ & $10822 \mathrm{a}$ & $3745 \mathrm{a}$ & $5.5 \mathrm{~b}$ & $286.3 \mathrm{~b}$ & 204.6 b & $81.7 \mathrm{~b}$ \\
\hline & Cookeville & $11 \mathrm{a}$ & $531 \mathrm{a}$ & $11630 \mathrm{a}$ & $4390 \mathrm{a}$ & $5.9 \mathrm{ab}$ & $259.6 \mathrm{~b}$ & $185.0 \mathrm{~b}$ & $74.7 \mathrm{~b}$ \\
\hline
\end{tabular}

${ }^{\mathrm{z}}$ Means within a column and transplant season followed by the same letter are not significantly different $(P \leq 0.05)$ using least squares means procedures; $\mathrm{n}=10$.

24) and nonimproved (Brazos-C, Brazos-D) genotypes were less apparent after 3 years in the field with regional genotypes (Fig. 1A and B) than previously reported for shorter time frames (Shoemake, 1996; Arnold and Shoemake, 1997). After 3 years in the field, a 30\% improvement in survival (Table 1) could be achieved by electing to plant the best regional genotype (TFS-09) versus the poorest adapted nonregional genotypes (Cookeville and WV-14). These data illustrate that substantial improvements in initial landscape performance of seed-propagated sycamore trees can be achieved by using regional genotypes over those from distant provenances, and that these differences persist for at least several years.

Further improvements in initial landscape performance of seed-propagated sycamores can be attained by transplanting in fall compared to spring or summer (Fig. 1C). While fall and spring transplanted trees grew well during the first 2 years after transplant, it was not until the third year after transplant that the summer transplanted stock resumed growth at a pace similar to that of spring transplants (Fig. 1C). Typically, within a transplant date, larger seedlings of various species have been reported to establish more rapidly than smaller seedlings (Campbell and Sorensen, 1984; Kormanik, 1986), however despite their larger size at transplant summer transplanted HSF suffered a lag in growth for $\approx 2$ years (Fig. 1C). Increased growth of fall transplanted stock compared to that of spring or summer transplanted stock was continued for 3 years across HSF of seed-propagated sycamore (Fig. 1C). Perhaps more importantly, survival of summer transplanted seedlings was substantially less (Fig. 1D). Initial mortality in the first year was minimal for fall and spring transplanted trees; survival at the end of the first growing season for summer transplanted trees was only $54 \%$. Survival remained high after 3 years for fall $(86 \%)$ and spring $(80 \%)$ transplanted stock, whereas survival of summer transplanted stock continued to fall (29\%). These data strongly support fall planting of sycamores in this region. One explanation for the poor growth of summer transplanted stock is the harsher environmental conditions related to the summer season. Alternatively, plants were substantially larger in the same size containers at summer transplant (time 0 , Fig. 1C), which may have resulted in a more rapid depletion of available moisture in the transplanted rootball during establishment.

ROOT GROWTH OF SEEDLING TRANSPLANTS. Daily root elongation had a significant $(P \leq 0.05)$ three-way interaction among HSF, season of transplant, and time after transplant (Fig. 2). For most other root regeneration measures significant two-way interactions $(P \leq 0.05)$ were found among the HSF and season of transplant (Table 2). With most measures, RRP was high during spring and summer and lower during fall (Table 2). Roots of all genotypes were not visible until $9 \mathrm{~d}$ after transplant in fall (Fig. 2A), whereas visible root elongation occurred within $6 \mathrm{~d}$ after spring (Fig. 2B) or summer (Fig. 2C) transplant. In the fall, Brazos-C had greater root elongation rates through $21 \mathrm{~d}$ after transplant than WV-14 or Cookeville HSF, and TFS-09 was greater on days 18 and 21 than the WV-14 or Cookeville HSF (Fig. 2A). In spring TFS-09 and Brazos-C had greater root elongation rates than WV-14 or Cookeville until day 15 , but no meaningful pattern of differences was apparent in spring after day 15 (Fig. 2B). In summer root elongation rates were similar among all four tested genotypes during the first 21 d post-transplant (Fig. 2C). Temperature conditions may have played a role in these observed seasonal responses as mean daily maximum, minimum, and average greenhouse atmospheric temperatures in the greenhouse were greatest in summer and least in fall, and varied most widely in spring (Table 3). However, inherent dormancy in root tissues of Malus $\times$ domestica Bork. (Arnold and Young, 1990b, 1991) and interactions of RRP with shoot dormancy and active shoot growth have been documented in many tree species (Zobel and Talbert, 1984). Fall transplants were entering dormancy, and this may have contributed to the slower initiation of root regeneration (Fig. 2A).

Across transplant seasons, the only new root regeneration characteristic that was consistent (not involved in a significant interaction) was that of days to the first root regenerated being visible at the observation panel. This parameter correctly separated the HSF with better post-transplant shoot growth during establishment from those that exhibited poorer shoot growth during establishment. Brazos-C (8 d) and TFS-09 HSF ( $8 \mathrm{~d})$ regenerated roots more rapidly following transplant $(P \leq 0.05)$ than WV-14 $(10 \mathrm{~d})$ and Cookeville HSF (11 d). Days to the first 10 regenerated roots and total number of regenerated roots were useful for differentiating $\mathrm{HSF}$ at fall and spring transplant, but not during summer (Table 2). New root number, surface area, root length, and new root weight per plant were inconsistent for separating HSF relative to field performance, particularly at summer trans- 
Table 3. Greenhouse air temperatures during $21 \mathrm{~d}$ root regeneration experiments with four half-sib families of Platanus occidentalis.

\begin{tabular}{llcc}
\hline Transplant & \multicolumn{3}{c}{$\begin{array}{c}\text { Greenhouse } \\
\text { atmospheric } \\
\text { temp }\left({ }^{\circ} \mathrm{C}\right)\end{array}$} \\
season & Mean & High & Low \\
\hline Fall & $17.9 \mathrm{c}^{\mathrm{z}}$ & $22.0 \mathrm{c}$ & $13.7 \mathrm{~b}$ \\
Spring & $20.5 \mathrm{~b}$ & $27.5 \mathrm{~b}$ & $13.5 \mathrm{~b}$ \\
Summer & $23.4 \mathrm{a}$ & $29.4 \mathrm{a}$ & $17.5 \mathrm{a}$
\end{tabular}

zMeans of temperatures within a column followed by the same letter are not significantly different $(P \leq 0.05)$ using least squares means procedures; $\mathrm{n}=21$.

plant (Table 2). Various measures of RRP have been found to be useful predictors of establishment of bareroot Liquidambar styraciflua L. (Kormanik, 1986) and container-grown Quercus shumardii Buckley (Arnold, 1996). Whitlow and Anella (1999) found a strong association between the ability of Acer rubrum L. genotypes to form adventitious roots and genotypic tolerance to flooding. As an alternative to assessing new root growth, it is noteworthy that in fall and summer total plant, shoot and transplanted rootball dry weights were as useful for predicting HSF field performance as days to the first root (Table 2); however these measures were inconsistent at spring transplant (Table 2). Seedling size has often been used as a grading tool in operational forestry plantings (Campbell and Sorensen, 1984), but caution should be exercised in using juvenile traits to predict long-term field (landscape) performance (Campbell and Sorensen, 1984; Zobel and Talbert, 1984).

WATER POTENTIAL AND $\mathbf{P}_{\mathbf{n}}$ GAS EXChange. For both midday and predawn water potentials, the interaction between transplant date and HSF and the main effects of HSF were not significant $(P \leq$ $0.05)$, while the main effects of time were significant. Plants were under mild water stress during the first few weeks post-transplant, with greater water stress evident after summer transplant despite regular irrigation. Mean midday water potentials during the first $21 \mathrm{~d}$ post-transplant decreased significantly $(P \leq 0.01)$ from fall $(-0.48 \pm 0.03 \mathrm{MPa})$ to spring $(-0.88 \pm 0.02 \mathrm{MPa})$, and again from spring compared to summer $(-1.05 \pm 0.02 \mathrm{MPa})$, while predawn water potentials increased significantly $(P \leq 0.05)$ from fall $(-0.27 \pm 0.02 \mathrm{MPa})$ compared to spring $(-0.22 \pm 0.01 \mathrm{MPa})$ transplant, but then decreased substantially in summer $(-0.34 \pm$ $0.01 \mathrm{MPa})$ indicating greater midday stress and poorer recovery at night in summer.

The ability of a seedling to maximize net photosynthesis $\left(\mathrm{P}_{\mathrm{n}}\right)$ while minimizing transpiration (E) affects productivity measures, such as increases in biomass (Larcher, 1995), and often is collectively referred to as water use efficiency (WUE). Platanus occidentalis is limited in nature to moist environments (Odenwald and Turner, 1996; Sternberg and Wilson, 1995) and is considered to be drought intolerant, developing marginal leaf necrosis and, frequently, premature leaf senescence when water stressed (Arnold, 2002). However, closely rated southwestern United States and Mexican species of Platanus are reportedly more drought tolerant (Arnold, 2002), thus, WUE might be of ecological importance for western ecotypes of $P$. occidentalis planted in xeric landscapes or for nursery production efficiency in drier regions.

Two days of withholding irrigation resulted in moderate stress levels $\left(-1.32 \pm 0.09 \mathrm{MPa} \Psi_{\text {leaf }}\right)$ compared to daily irrigated plants $\left(-0.77 \pm 0.11 \mathrm{MPa} \Psi_{\text {leaf }}\right)$. This moderate drought stress caused a decrease in $\mathrm{P}_{\mathrm{n}}\left(15.7 \pm 0.9\right.$ vs. $\left.11.9 \pm 0.9 \mu \mathrm{mol} \cdot \mathrm{m}^{-2} \cdot \mathrm{s}^{-1} \mathrm{CO}_{2}\right)$ and $\mathrm{g}_{\mathrm{s}}\left(1.18 \pm 0.12\right.$ versus $\left.0.76 \pm 0.12 \mathrm{~cm} \cdot \mathrm{s}^{-1}\right)$ across $\operatorname{HSF}(P \leq 0.05)$. There was a significant drought stress by family interaction for $\mathrm{E}$ (Fig. 3A, $P \leq 0.04$ ) and $\mathrm{C}_{\mathrm{i}}$ (Fig. 3B, $P \leq 0.01$ ). Genotypes did not differ in $\mathrm{E}$ under low water deficit conditions, but under greater water stress TFS-09 E decreased while E remained steady for Cookeville (Fig. 3 A). For TFS-09 $C_{i}$ was reduced by the increased water deficit, but $\mathrm{C}_{\mathrm{i}}$ was not lowered with Cookeville (Fig. 3B), suggesting stomata of TFS-09 may close as a drought avoidance mechanism. Although TFS-09 and Cookeville did not differ in $P_{n}$ on a unit leaf area basis, and whole-plant $P_{n}$ was not directly measured in this study, a larger canopy [greater leaf number, (64.8 versus $20.2, P \leq 0.5)$ and total surface area (5598 versus $\left.\left.3890 \mathrm{~cm}^{2}, P \leq 0.05\right)\right]$ for TFS-09 seedlings suggests a potential for greater whole plant $\mathrm{P}_{\mathrm{n}}$. Overall, native Texas HSF exhibited some characteristics of more arid region genotypes, such as smaller leaves (74.4 and $99.8 \mathrm{~cm}^{2} /$ leaf for TFS-09 and Brazos-C versus 109.8 and $142.0 \mathrm{~cm}^{2} /$ leaf for WV-14 and Cookeville, respectively) relative to nonregional $\mathrm{HSF}$.

AdVEntitious roOt REgENERATION FROM CUTTINGS. Although significant differences $(P \leq 0.05)$ were found among clones and physiological stage of cutting development for rooting percentage,

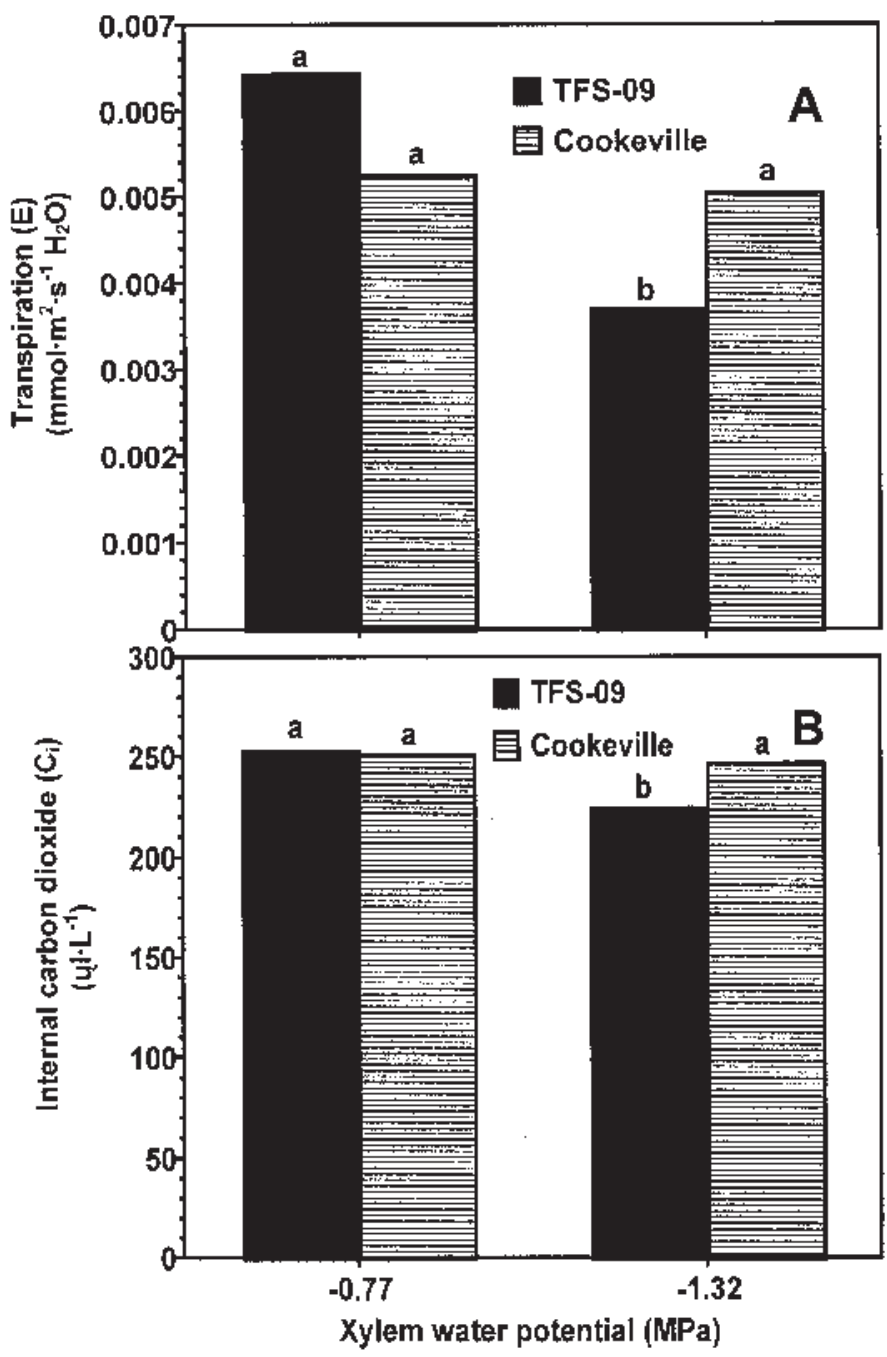

Fig. 3. Interactions between sycamore half-sib families, TFS-09( $\square$ ) and Cookeville ), and water stress levels on leaf transpiration (A) and internal carbon dioxide concentration of the leaves (B); point estimates are the means of 10 observations; bars with a graph topped by the same letters are not significantly different at $(P \leq 0.05)$. 
number of roots per cutting, or root length (data not presented), statistical analysis indicated no significant correlations $(P \leq 0.05)$ between the quality (root number or length) or quantity (rooting percentage) of rooted cuttings and HSF responses in the field (Fig. 4). Cookeville clone 5 had the greatest quantity and quality of rooted cuttings of all clones in both HSF from hardwood cuttings (data not presented), but this same clone was a very poor performer in the field (Fig. 4). This illustrates the danger in selecting genotypes for landscape use based on their potential for vegetative propagation instead of field or landscape growth potential.

Fig. 4. Interactions among ten sycamore clones from two half-sib families, TFS-09 (solid symbols) and Cookeville (open symbols), and time after transplant on height (A) and trunk diameter (B); values are means of 15 observations; significant $P$ $\leq 0.05$ polynomial regression equations are presented for each clone with clones from the TFS-09 family represented by dashed lines of varying lengths ( $r^{2}$ ranging from 0.93 to 0.99 ) and clones from the Cookeville family represented by dashed lines with dots in varied combinations ( $r^{2}$ or $R^{2}$ ranging from 0.44 to 0.98 ).
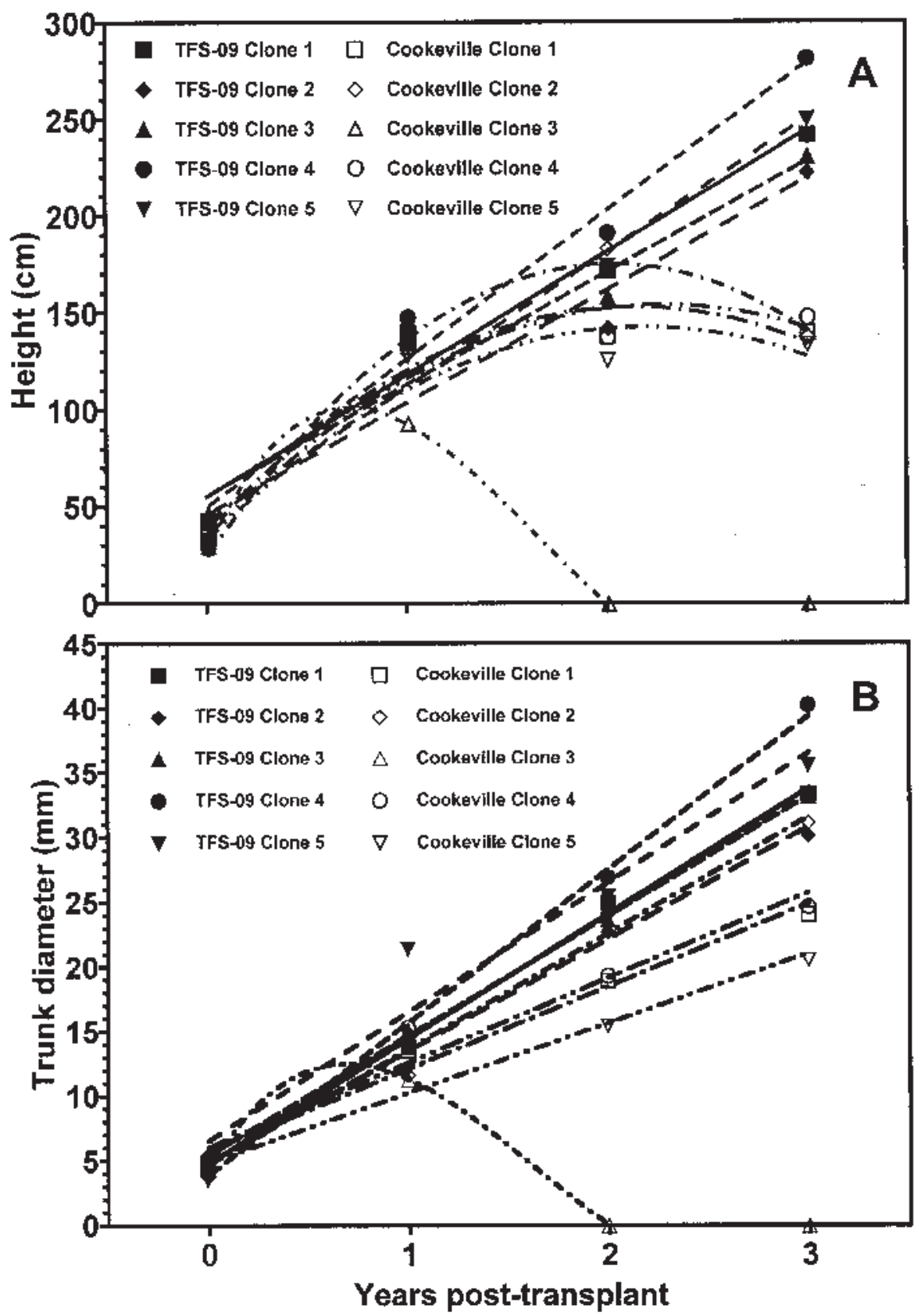

Although clonal production of plants is typically a reliable method of propagating morphologically stable shoot growth traits, less is known about root system architecture and its relationship to clonal propagation. Rootstocks have been long utilized for imparting certain traits to a scion such as reduced vegetative growth or tolerance to adverse soils or disease, however, Oddiraju et al. (1994) reported an absence of transfer of profuse versus scant root development to ramets of western black cherry clones [Prunus serotina Ehrh. var. virens (Wooton \& Standley) F. Shreve]. Likewise, Whitcomb (1984) reported a loss of certain shoot morphology traits on two genotypes when propagating rooted cuttings of 13 clones of Ulmus parvifolia Jacq. from shoot tips.

FiELd RESPONSES OF CLONES. Field growth responses of clones within the two HSF were generally consistent with the field responses of seedling populations from within those same HSF(Fig. 4 ), confirming that field responses of vegetatively propagated clones from within superior HSF can improve landscape establishment, i.e. capture narrow sense heritability (Zobel and Talbert, 1984; Zobel et al., 1987). Although nearly all of the TFS-09 clones grew taller (Fig. 4A) and had greater trunk diameters (Fig. 4B) than the Cookeville clones, there was considerable variation within individual HSF, particularly within the Cookeville HSF. Overall superior field performance of TFS-09 clones increased over time, with a $50 \%$ or greater increase in height of TFS-09 over that of Cookeville clones (Fig. 4A). A similar response occurred with trunk diameter, however, there was an overlap in responses among the poorest growing TFS-09 clone and the best growing clone of the Cookeville group (Fig. 4B). This illustrates the potential pitfalls in selecting a single clone from a given superior performing seedling population (provenance, seed source, or land race) and promoting it as a superior selection unless specific field testing of the clone is conducted to confirm its nursery and landscape responses in comparison to the seedling population.

ROOT GROWTH OF CLONES. No significant interactions $(P \leq 0.05)$ were present for root regeneration measures of HSF and days from transplant with the cutting-propagated, container-grown plants. Across clones, the TFS-09 HSF regenerated an average of 74.1 new roots per plant compared to only 22.7 new roots for the Cookeville HSF $(P \leq 0.05)$. Fewest days to the first observed root was less for TFS-09 clones (15.7 d) than for Cookeville (22.8 d), however mean daily root elongation $(0.32 \mathrm{~cm}$ versus $0.26 \mathrm{~cm})$ and the number of days to the first 10 roots observed $(22.6 \mathrm{~d}$ versus $25.2 \mathrm{~d})$ did not differ $(P \leq 0.05)$ among families when trees were derived from vegetative propagation. Results for number of new roots regenerated and the first roots regenerated were consistent with family differences seen in the earlier studies with seedling stock (Table 2). Root elongation rates were slower (more days until visible roots were present) with the vegetatively propagated plants than 
with seedling-grown plants, but elongation rates across time after transplant followed a similar pattern to that of the seedlingderived plants, and differences may have been due to variation in the greenhouse conditions from one experiment to the next. There appears to be no correlation between the ability of clones to root adventitiously from shoot cuttings, regardless of cutting developmental stage, and their RRP when new roots originate from root tissue. This is perhaps not surprising as the new roots would be arising from different tissues when initiated from stem versus root tissues.

Data presented in this series of experiments demonstrate the importance of utilizing locally or at least regionally adapted provenances as seed sources for nursery production and subsequent landscape use of seed-propagated sycamore. Further improvements in landscape responses are possible with vegetative propagation of superior clones from within the better-adapted HSF, however this performance needs to be verified for individual clones prior to recommending their use over seedling materials. Rapidity of root regeneration outside the original rootball appears to be the best predictive characteristic among new root growth measures of successful field establishment across transplant seasons. Likewise, overall plant, shoot, and transplanted root dry mass were good predictors of successful establishment within fall and summer transplant, but not necessarily between transplant times as summer establishment was poorest despite it having larger plants at transplanting from the nursery. Adventitious root regeneration from shoot cuttings was not consistent with adventitious RRP of the same genotypes from root tissues. Differential leaf morphology and gas exchange characteristics between TFS-09 (more vigorous field response) and Cookeville (less vigorous) HSF suggest that regional Texas genotypes may have some better drought adaptations than the nonregional HSF. Substantial economic implications may be associated with the simple act of seed source selection when producing sycamore for aesthetic landscape plantings.

\section{Literature Cited}

Arnold, M.A. 2002. Landscape plants for Texas and environs, 2nd ed. Stipes Publ. L.L.C., Champaign, Ill.

Arnold, M.A. 1996. Mechanical correction and chemical avoidance of circling roots differentially affect post-transplant root regeneration and field establishment of container-grown shumard oak. J. Amer. Soc. Hort. Sci. 121:258-263.

Arnold, M.A. and W.E. Davis. 1994. Adaptability of forest tree improvement program seed sources of sycamore and sweetgum to ornamental field nursery production and transplant establishment following production. J. Environ. Hort. 12:190-192.
Arnold, M.A. and E. Young. 1990a. Use of dyes to facilitate measurement of new root growth of apple. HortScience 25:116-118.

Arnold, M.A. and E. Young. 1990b. Growth and protein content of apple in response to root and shoot temperatures following chilling. HortScience 25:1583-1588.

Arnold, M.A. and E. Young. 1991. Influence of chilling at 5 C, suckering and top growth on root regeneration in seedlings of Malus spp. J. Hort. Sci. 66:623-633.

Campbell, R.K. and F.C. Sorensen. 1984. Genetic implications of nursery practices, p. 183-191. In: M.L. Duryea and T.D. Landis (eds.). Forest nursery manual: production of bareroot seedlings. Martinus Nijhoff/W. Junk Publ., The Hague, Netherlands.

Kormanik, P.P. 1986. Lateral root morphology as an expression of sweetgum seedling quality. For. Sci. 32:595-604.

Larcher, W. 1995. Physiological plant ecology. Springer, New York.

Nebgen, R.J. 1980. Variation in, inheritance of, and correlations between a number of growth and form traits in three sycamore populations. MS thesis. Texas A\&M Univ., College Station, Texas.

Oddiraju, V.G., C.A. Beyl, P.A. Barker, and G.W. Stutte. 1994. Container size alters root growth of western black cherry as measured via image analysis. HortScience 29:910-913.

Odenwald, N. and J. Turner. 1996. Identification, selection and use of southern plants for landscape design, 3rd ed. Claitor's Publ. Co., Baton Rouge, La.

St. Hilaire, R. and W.R. Graves. 2001. Stability of provenance differences during development of hard maple seedlings irrigated at two frequencies. HortScience 36:654-657.

Shoemake, L.J. 1996. Effects of half-sib family selection on the root regeneration potential and initial landscape establishment of containergrown sycamore, Platanus occidentalis L. MS thesis. Texas A\&M Univ., College Station, Texas.

Shoemake, L.J. and M.A. Arnold. 1997. Half-sib family selection improves container nursery and post-transplant landscape performance of sycamore. J. Environ. Hort. 15:126-130.

Sternberg, G. and J. Wilson. 1995. Landscaping with native trees for the northeast, midwest, midsouth, and southeast. Chapters Publ. Ltd., Shelburne, Vt.

Wells, O.O. and J.R. Toliver. 1987. Geographic variation in sycamore (Platanus occidentalis L.). Silvae Genetica 36:154-159.

Whitcomb, C.E. 1984. Propagating trees from cuttings. Res. Rpt. Okla. Agr. Expt. Sta. p. 25-26.

Whitlow, T.H. and L.B. Anella. 1999. Response of Acer rubrum L. (red maple) genotypes and cultivars to soil anaerobiosis. Proc. Intl. Symp. on Urban Tree Health. Acta Hort. 496:393-397.

Zobel, B. and J. Talbert. 1984. Applied forest tree improvement. John Wiley and Sons, New York.

Zobel, B.J., G. Van Wyk, and P. Stahl. 1987. Growing exotic forests. John Wiley and Sons, New York.

Zwack, J.A., W.R. Graves, and A.M. Townsend. 1999. Variation among red and freeman maples in response to drought and flooding. HortScience 34:664-668. 